\title{
INCIDENCE OF POSITIVE WASSERMANN REACTIONS IN FOUR HUNDRED AND EIGHTY-FOUR SUP- POSEDLY NONSYPHILITIC PATIENTS
}

\author{
ADMITTED TO A GENERAL HOSPITAL *
}

ROBERT A. KILDUFFE, M.D.

Director of Laboratories, Pittsburgh and McKeesport Hospitals;

Serologist, Providence Hospital

PITTSBURGH

In a recent paper concerned with the results of Wassermann tests in supposedly nonsyphilitic persons, Williams ${ }^{1}$ comments on the fact that information as to the incidence of syphilis in the general public is based on figures obtained from clinics largely devoted to the study of syphilis, and, therefore, to that extent is liable to be misleading. $\mathrm{He}$ further remarks that, apparently, few studies of the Wassermann reaction in persons supposedly free from syphilis have been published, quoting those of Stokes at the Mayo Clinic and Solomon ${ }^{2}$ as being all that are available.

The present paper was largely prompted by a consideration of these facts and comprises a study of Wassermann tests taken as a routine measure in a moderately large number of cases, covering a variety of medical, gynecologic, and surgical conditions in patients admitted to the Pittsburgh Hospital during the period from May, 1920, to May, 1921. A tabulation of these cases with the admitting diagnosis is given in Table 1 , which serves to indicate the fairly wide range of conditions investigated.

In the gynecologic' and obstetric services of this hospital, a Wassermann test is made on every patient as a routine measure; in the medical service the test is made on the greater majority of patients, and in approximately 20 per cent. of the surgical cases admitted, so that the series, while not comprising all of the admissions to the hospital during the time stated, is, nevertheless, fairly representative in its character and extent.

For the purpose of this investigation, from the Wassermann reports during the period noted, only those cases were tabulated in which the test was taken more or less as a matter of routine, cases with syphilis,

* From the Laboratories of the Pittsburgh Hospital.

1. Williams, J. R.: A Study of the Wassermann Reaction in a Large Group of Supposedly Nonsyphilitic Individuals, Including Large Groups of Diabetics and Nephritics, Am. J. Syphilis 2:284 (April) 1921.

2. Solomon, H. C.: Agreement in Results of the Wassermann Reaction, J. A. M. A. 74:788 (March 20) 1920. 
or in which syphilis was an evident probability being excluded. When the Wassermann reaction was positive, the history was searched for clinical or historical data corroborative of the test, the degree of success depending entirely on the keenness of the resident and visiting staff in this particular. A total of 484 cases with 567 Wassermann reactions were thus investigated, with results as indicated.

TABLE 1.-RAnge of Conditions Investigated

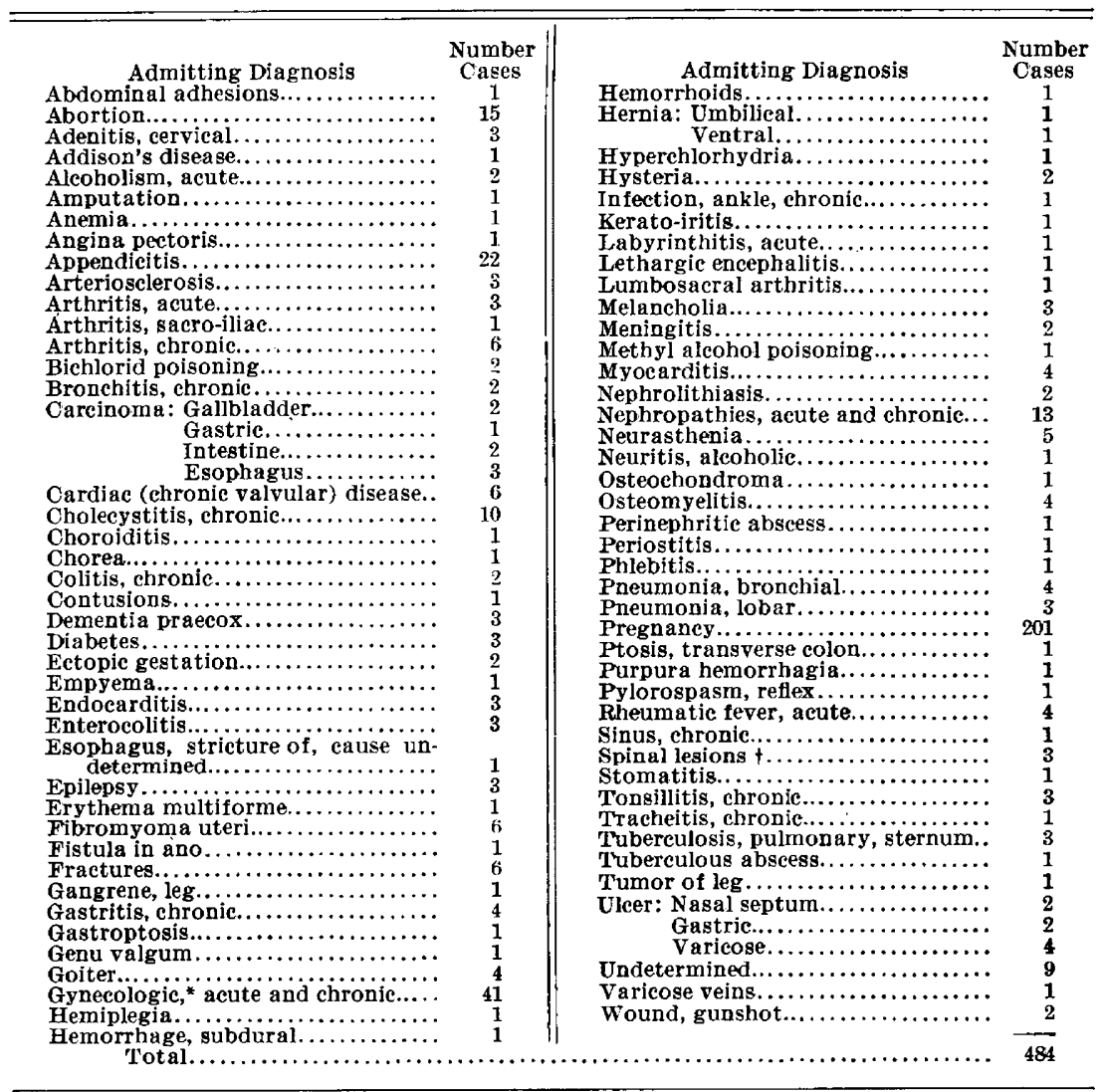

* This includes acute and chronic infections, cases admitted for repair, plastic operations, etc.

+ Includes tumors and injuries.

The small number of repeated tests is largely due to the short stay of many of the patients in the hospital and, also, to the failure of the attending physicians to requisition additional examinations.

\section{METHOD OF PROCEDURE}

The Wassermann tests were all made by me in the laboratories of the Pittsburgh Hospital, using a triple antigen battery composed of cholesterinized ( 0.4 per cent.) extract of human heart, acetone-insoluble 
TABLE 2.-Cases Giving Positive Reactions with All Antigens*

\begin{tabular}{|c|c|c|c|c|c|c|}
\hline \multirow{2}{*}{ Case } & \multirow{2}{*}{ Sex } & \multirow{2}{*}{$\begin{array}{l}\text { Admitting } \\
\text { Diagnosis }\end{array}$} & \multicolumn{3}{|c|}{ Wassermann Test $†$} & \multirow{2}{*}{ History of Syphilis } \\
\hline & & & 0 & $\mathbf{A}$ & $\mathbf{s}$ & \\
\hline 191 & Male & $\begin{array}{l}\text { Fracture first, } \\
\text { second and third } \\
\text { metatarsals }\end{array}$ & +++ & ++++ & $+++t$ & $\begin{array}{l}\text { Chancre eight years ago; } \\
\text { no treatment }\end{array}$ \\
\hline 9006-A & Male & $\begin{array}{l}\text { Chronic infection } \\
\text { of ankle }\end{array}$ & +++ & $+++t$ & $+++t$ & $\begin{array}{l}\text { Denied; ankle soreness of } \\
\text { three years" duration }\end{array}$ \\
\hline 9736-A & Male & $\begin{array}{l}\text { Chronic valvular } \\
\text { heart disease }\end{array}$ & ++++ & $+++t$ & ++++ & Denied \\
\hline 479 & Female & $\begin{array}{l}\text { Abortion, spon- } \\
\text { taneous }\end{array}$ & $+t+t$ & $++t+$ & ++++ & None \\
\hline 478 & Female & $\begin{array}{l}\text { Chronic inter- } \\
\text { stitial nephritis }\end{array}$ & $+++t$ & ++++ & ++++ & $\begin{array}{l}\text { Persistent headache for } \\
\text { three months; three mis- } \\
\text { carriages; syphilis denied }\end{array}$ \\
\hline 455 & Female & "Nervousness" & ++++ & ++++ & $+t+t$ & $\begin{array}{l}\text { Denied; husband states } \\
\text { boarder had syphilis and } \\
\text { wife had persistent ulcer } \\
\text { on nose; spinal fluid } 4+ \\
\text { all antigens; colloidal } \\
\text { gold reaction, } 5555544300\end{array}$ \\
\hline 375 & Male & Tabes? & ++++ & $+t+t$ & ++++ & $\begin{array}{l}\text { Had gonorrhea; d e n i e s } \\
\text { chancre; complains of } \\
\text { lancinating pains }\end{array}$ \\
\hline 975 & Male & $\begin{array}{l}\text { Chronic valvular } \\
\text { heart disease }\end{array}$ & ++++ & $+++t$ & $++t$ & Denied \\
\hline$\stackrel{?}{1208}$ & $\begin{array}{l}\text { Female } \\
\text { Male }\end{array}$ & $\begin{array}{l}\text { Diabetes mellitus } \\
\text { Bronchopneu- } \\
\text { monia }\end{array}$ & $\begin{array}{l}++++ \\
+++\end{array}$ & $\begin{array}{l}++++ \\
+++t\end{array}$ & $\stackrel{++}{++}+$ & $\begin{array}{l}\text { None } \\
\text { None }\end{array}$ \\
\hline 1256 & Female & Umbilical hernia & ++++ & ++++ & ++++ & $\begin{array}{l}\text { No history obtainable; } \\
\text { patient irrational; spina] } \\
\text { fuid } 4+, \text { all antigens }\end{array}$ \\
\hline 1251 & Male & $\begin{array}{c}\text { Cerebrospinal } \\
\text { lesion }\end{array}$ & ++++ & ++++ & $+t+t$ & Denied \\
\hline 792 & Male & $\begin{array}{c}\text { Perinephritic } \\
\text { abscess }\end{array}$ & ++ & & ++ & $\begin{array}{l}\text { Denied; soldier in Mexican } \\
\text { army three years }\end{array}$ \\
\hline 74 & & $\begin{array}{l}\text { Infected varicose } \\
\text { ulcer }\end{array}$ & ++++ & $+++t$ & $+++t$ & $\begin{array}{l}\text { Denied; seven pregnancies } \\
\text { with two miscarriages }\end{array}$ \\
\hline 477 & Male & Gastritis & +++ & $\ldots \ldots \ldots$ & ++++ & Syphilis seven years ago. \\
\hline
\end{tabular}

* Cholesterinized extract human heart (0.4 per cent. cholesterin); acetone-insoluble lipoids human heart; alcoholic extract syphilitic liver.

$\dagger \mathrm{C}$, eholesterinized extract; $A$, acetone extract; $s$, liver extract.

† Venereal history not noted on chart.

TABle 3.-Cases Reacting with Cholesterinized and Acetone Antigens ONLY*

\begin{tabular}{|c|c|c|c|c|c|}
\hline \multirow{2}{*}{ Case } & \multirow{2}{*}{$\operatorname{Sex}$} & \multirow{2}{*}{$\begin{array}{l}\text { Admitting } \\
\text { Diagnosis }\end{array}$} & \multicolumn{2}{|c|}{ Wassermann Test $t$} & \multirow{2}{*}{ History of Syphilis } \\
\hline & & & $\mathbf{O}$ & $\mathbf{A}$ & \\
\hline 241 & Female & Ptosis of transverse & +++ & + & Denied; provocative Wassermann \\
\hline 9198-A & Female & $\begin{array}{l}\text { Gastro-enteritis; cys- } \\
\text { tic goiter }\end{array}$ & $+t+$ & $+t$ & Denied \\
\hline $9558-\mathrm{A}$ & Male & Hemiplegia.......... & +++ & +++ & $\begin{array}{l}\text { None obtainable on account of } \\
\text { mental condition }\end{array}$ \\
\hline 95 & Male & Stomatitis........... & ++++ & ++++ & Denied; improved under specific \\
\hline$?$ & Female & Olcer nasal septum... & $+t+t$ & $+t+t$ & Denied \\
\hline$?$ & Female & Chronie tonsillitis.... & ++++ & +++ & $\begin{array}{l}\text { Denied; neurotic; persistent fron- } \\
\text { tal headache }\end{array}$ \\
\hline $\begin{array}{l}641 \\
838\end{array}$ & $\begin{array}{l}\text { Female } \\
\text { Female }\end{array}$ & $\begin{array}{l}\text { Lobar pneumonia.... } \\
\text { Multiple fibroids..... }\end{array}$ & $\begin{array}{l}+++ \\
++++\end{array}$ & $\stackrel{+}{+}$ & $\begin{array}{l}\text { None } \$ \\
\text { None }\end{array}$ \\
\hline 595 & Male. & Pylorospasm......... & $++t$ & ++ & $\begin{array}{l}\text { Chancre } 20 \text { years previously; } \\
\text { provocative Wassermann reac- } \\
\text { tion } 4+, \text { all antigens }\end{array}$ \\
\hline
\end{tabular}

* Cholesterinized extract human heart; acetone-insoluble lipolds human heart.

t $C$, cholesterinized extract; $A$, acetone extract.

$\ddagger$ No venereal history noted on chart. 
lipoids of human heart, and an alcoholic extract of syphilitic fetal liver. All antigens were titrated at monthly intervals and used in doses of five times the titrated antigenic unit, which amount was always from ten to twenty times less than the anticomplementary unit as determined by titration. An antisheep hemolytic system was used, the sheep being bled the day preceding the test and the corpuscles used in 2.5 per cent. suspension; amboceptor and complement were titrated the day of the test and used in doses of two units. Incubation was for one hour in the water bath at $38 \mathrm{C}$. The usual controls were always included.

A serum was considered positive if there was absence of hemolysis in ++ degree or more in the cholesterinized antigen, even though the acetone and liver extracts were negative, as, to quote Kolmer, ${ }^{3}$ with whose statement $I$ am in thorough accord, and on the basis of data presented elsewhere, ${ }^{4}$ "I have learned from experience to place reliance upon results obtained with a properly prepared and titrated cholesterinized extract."

\section{RESULTS OF TESTS}

In Table 2 are shown the cases in which the patients gave a reaction with all antigens, together with the data concerning them. Of these, there were fifteen, or approximately 3 per cent.; excluding the pregnant women, 6 per cent. of the series.

In these fifteen cases, there were only two patients (Nos. 455 and 375 ) in whom syphilis might have been suspected; the remaining thirteen were persons suffering from syphilis, in whom the disease was not suspected and would not have been discovered without a Wassermann test.

In nine of these cases, a history substantiating the serologic findings to a greater or less degree was elicted; in seven cases syphilis was definitely denied, and in three cases no venereal history was noted on the chart. There was one case of diabetes and one of bronchopneumonia included in this group, which will be discussed later.

Table 3 shows the cases in which there was a reaction to both acetone and cholesterinized antigens, the liver extract reaction being negative. There were nine patients in this group or approximately 2 per cent.; excluding pregnant women, approximately 4 per cent. In only one of these cases was a history of syphilis obtained; in two no venereal history was noted; one patient was mentally incapable of giving any history, and in five cases syphilis was definitely denied. This group also included one case of lobar pneumonia.

3. Kolmer, J. A.: Infection, Immunity, and Specific Therapy, Ed. 2, Philadelphia, W. B. Saunders Company, p. 445.

4. Kilduffe, R. A.: Concerning the Specificity of Cholesterinized Antigens in the Serologic Diagnosis of Syphilis, Arch. Dermat. \& Syph. 3:598 (May) 1921. 
In Table 4 are shown the cases in which there was a reaction to cholesterinized antigen alone, twenty-three, or approximately 10 per cent. This includes one case of diabetes, one of bronchopneumonia and one of pulmonary tuberculosis; none of the group presented a clinical entity prominently suggestive of syphilis. Syphilis was definitely denied in fifteen cases; in four no history is noted; and in four cases a definite history of syphilitic infection was obtained.

Table 4.-Cases Reacting with Cholesterinized Antigen Only*

\begin{tabular}{|c|c|c|c|c|}
\hline Case & Sex & $\begin{array}{l}\text { Admitting } \\
\text { Diagnosis }\end{array}$ & $\begin{array}{c}\text { Wasser- } \\
\text { mann Test, } \\
\mathbf{C}\end{array}$ & History of Syphilis \\
\hline$?$ & Male & Nephrolithiasis....... & ++++ & Denied; soldier, three years \\
\hline 394 & Fernale & Abortion.............. & $++t+$ & $\begin{array}{l}\text { Five miscarriages; husband had syph- } \\
\text { ilis nine years ago; miscarriages oc } \\
\text { eurred since then; husband has posi } \\
\text { tive Wassermann reaction }\end{array}$ \\
\hline 496 & Male & Chronic cholecystitis. & $+t+t$ & Chancre and bubo seven years ago \\
\hline 123 & Female & Salpingo-oophoritis.. & +++ & $\begin{array}{l}\text { Denied; has had one abortion; cervica } \\
\text { and epitrochlear adenopathy; provo } \\
\text { cative Wassermann reaction: } \mathbf{C}, 4+ \\
\mathbf{A}, 4+; \mathbf{8}, 0\end{array}$ \\
\hline 434 & Male & $\begin{array}{l}\text { Fracture of jaw; } \\
\text { gunshot wound face }\end{array}$ & $++t+$ & Denied \\
\hline 1517 & Female & Sacro-iliac arthritis... & $+t+$ & Denied \\
\hline 692 & Female & Chronic cholecystitis & $+++t$ & Denied; has had four miscarriages \\
\hline 1495 & Male & Bronchopneumonia... & $+t+t$ & Denied \\
\hline 1277 & Female & Arteriosclerosis....... & $+\dot{t}+$ & Denied \\
\hline 1447 & Female & Laceration of cervix & $++t$ & $\begin{array}{l}\text { Denied; single; has had one child; } \\
\text { "vaginal abscess" five years ago }\end{array}$ \\
\hline 1133 & Male & Diabetes............ & $+++t$ & Denied \\
\hline 1241 & Male & Uleer of leg; diabetes & & Denied \\
\hline 979 & Female & Laceration of cervix & $++t+$ & $\begin{array}{l}\text { Denied; two miscarriages in four preg } \\
\text { nancles }\end{array}$ \\
\hline 1349 & Female & $\underset{\text { losis }}{\text { Pulmonary tubercu- }}$ & ++++ & None $t$ \\
\hline 1034 & Female & Chronic cholecystitis & ++++ & Denied; two pregnancies with one mis \\
\hline 946 & Female & Salpingo-oophoritis.. & $++t+$ & None \\
\hline 1280 & Male. & $\begin{array}{c}\text { Chronic interstitial } \\
\text { nephritis }\end{array}$ & +++ & -7 \\
\hline 1242 & Female & Cervicitis, metritis.... & ++++ & History of "gumma of knee" on pre- \\
\hline 201 & Male & $\begin{array}{c}\text { Tuberculosis of ster- } \\
\text { num }\end{array}$ & ++ & $\begin{array}{l}\text { Denied; provocative test negative, al } \\
\text { antigens }\end{array}$ \\
\hline 1656 & Female & Goiter.............. & +++ & $\begin{array}{l}\text { Chancre on tonsils followed by secon } \\
\text { dary infection five years ago }\end{array}$ \\
\hline 1247 & Female & $\begin{array}{c}\text { Chronie valvular } \\
\text { heart disease }\end{array}$ & $++t+$ & Denied \\
\hline 1013 & Female & Melancholia........... & ++++ & $\begin{array}{l}\text { None obtainable; patient irrational; } \\
\text { one miscarriage }\end{array}$ \\
\hline 336 & Femạle & Chronic endocarditis & ++++ & Denied; has had eight miscarriages \\
\hline
\end{tabular}

* Cholesterinized (0.4 per cent.) extract human heart.

+ No venereal history noted on chart.

In 201 pregnant women, 10, or 5 per cent., gave positive reactions with the cord blood; in only one of these was the blood from the mother direct also ++++ , and in none could a specimen be obtained from the father. There was no history of syphilis in any case.

Including the pregnant women, fifty-seven patients in the series of 484 , or approximately 12 per cent., gave positive Wassermann reactions of varying degree; excluding the pregnant women, of 283 patients with varied medical and surgical conditions, forty-seven, or 6 per cent., gave positive reactions. 
In a survey of the results obtained in cases manifesting various clinical conditions, there are several points of interest.

In seven cases of pneumonia, three of the patients gave positive reactions, exemplifying the fact that during the febrile period of the disease positive complement-fixation reactions with syphilitic antigens are not infrequently obtained, a finding which has been reported by numerous observers. Unfortunately, none of these patients were retested when afebrile, at which time negative reactions could have been expected.

In two out of three cases of diabetes, positive reactions were obtained, several tests being made in one case with identical results, the patient having a high sugar content of the urine and blood with a marked acetonuria. No history of syphilis could be obtained.

\section{COMMENT}

In the light of our present knowledge, the explanation of the occurrence of positive Wassermann reactions in persons having diabetes, a finding which has been reported by numerous observers, is a matter presenting some difficulty, unless, as has been suggested, diabetes can be accepted as an evidence of syphilis, which yet remains to be proved.

Williams ${ }^{1}$ reports a study of 337 cases of diabetes. There were sixteen cases in which, at one time or another, in forty-five tests of the patients, twenty-two gave positive Wassermann reactions of varying degree, and in which he gives cholesterol determinations according to the method of Bloor. Without advancing an increased cholesterol content of the blood as a factor in the causation of the positive Wassermann reactions, he calls attention to the fact that in practically all cases in which the serum was anticomplementary, the blood cholesterol was increased. A study of his tables fails to reveal any apparent relation between the blood cholesterol and the occurrence of positive or anticomplementary reactions, many of the patients in whom at one time the reactions were positive giving, later, negative reactions, with a highly increased cholesterol content, examples being a ++++ Wassermann reaction with $237 \mathrm{mg}$. of cholesterol, which later became negative with $288 \mathrm{mg}$.; and another ++++ Wassermann reaction with $237 \mathrm{mg}$., which later became negative with $530 \mathrm{mg}$. Moreover, in many cases in which increased cholesterol was manifested, the reactions were not anticomplementary.

In this connection the recent paper of Craig and Williams ${ }^{5}$ is of great interest. These investigators, working with rabbits, caused an increase of blood cholesterol of as much as 680 per cent. without,

5. Craig, C. F., and Williams, W. C.: Experimental Observations upon the Effect of Cholesteremia on the Results of the Wassermann Test, Am. J. Syphilis 5:392 (July) 1921. 
in any instances, being able to produce a positive Wassermann reaction, and concluded, as a result of their experiments, that there is no relation between the cholesterol content of the blood serum in rabbits and the results of the Wassermann tests. These findings would indicate the advisability of parallel Wassermann tests and cholesterol determinations in the human being.

Returning to the question of diabetes in its relation to positive Wassermann reactions, there remains a possibility that some cases of diabetes may be of syphilitic origin, or that at least syphilis may be coincidental.

Discussing this conjecture, Williams remarks that variations in the Wassermann reaction in the absence of specific treatment are "most anomalous" and "do not conform to the usual experience with the Wassermann reaction in syphilis, namely, that when syphilis is evident and the reaction positive, it remains positive until altered by specific treatment."

This statement will hardly be unanimously concurred in by serologists in general. Experience has shown that marked and unaccountable variations in the results of Wassermann tests on persons having syphilis may occur in the absence of specific treatment. This is well shown by the work of Thaysen ${ }^{6}$ reporting the results of repeated Wassermann tests on sixty-six persons, twenty-three of whom were known to be syphilitic, with a wide variation in the results obtained from positive to negative, and with many fluctuations, no cause for which could be adduced.

In 110 persons suffering from nephritis, studied by Williams, positive reactions occurred in one case; in thirteen persons having nephritis in the present series, two positive Wassermann reactions were obtained, a suggestive history of repeated miscarriages being elicited in one of the two cases.

In six cases of chronic valvular disease, two positive reactions were obtained, a history of syphilis being denied in both cases.

Of interest are the cases in which there is reaction to the cholesterinized extract only. Of twenty-three cases a definite history of syphilis was obtained in four; and in ten cases the history of clinical findings were very suggestive (miscarriages, adenopathy, increased knee-jerks, suspicious social history, etc.).

\section{CONCLUSIONS}

Although it is appreciated that the number of cases in this series is too small to permit far reaching conclusions, the series is comprehensive enough and the results of sufficient interest to indicate the

6. Thaysen, T. E.: Spontaneous Variations in the Strength of the Wassermann Reaction, Acta med. Scandinav. 55:281 (June 17) 1921. 
value of an extensive study along these lines, which it is to be hoped will be undertaken by others more capable and possessing a greater supply of clinical material.

Even this small series presents sufficient evidence to indicate the advisability and value of a routine Wassermann test on all patients admitted to hospitals at least; not so much from an epidemiologic or statistical standpoint, but as resulting in the initiation of truly specific therapy in a certain number of cases otherwise missed. For these reasons the practice is to be strongly urged and recommended.

It is obvious that any conclusions to be drawn from the results of Wassermann tests should be governed by the same rules of common sense that apply to all laboratory examinations; all should be interpreted in the light of their relation to the particular patient, as forming a - part of all findings on the sum total of which the diagnosis should depend. Equally obviously, one should not expect accurately to evaluate any finding, laboratory or clinical, unless it is closely correlated with all the knowledge and information pertaining to the particular case. Certainly, both positive and negative Wassermann reactions are best corroborated by additional tests and interpreted in conjunction with a careful and minute investigation of the history and clinical condition.

The value of the Wassermann test depends mainly on the care with which it is interpreted, which, in turn, depends on a thorough understanding of its limitations; these, to a great extent, are closely related to technical details of the reaction, with which the clinician should be sufficiently familiar to interpret properly the reports received.

\section{SUM MARY}

1. The results of 567 Wassermann tests on 484 unselected patients admitted to hospital are reported, with some discussion of the findings.

2. In 201 cases of pregnancy, one positive reaction with cord blood reaction corroborated by a positive reaction in the blood of the mother occurred, an incidence of 0.5 per cent. Nine positive reactions in the cord blood alone were obtained.

3. In 283 cases presenting miscellaneous medical and surgical conditions, forty-seven positive reactions occurred, an incidence of 6 per cent.

4. In the 494 cases of the entire series, appruximately 12 per cent. of positive reactions were obtained; in twenty of the fifty-seven cases in which the patients reacted positively, there were either clinical or historical findings to corroborate the results of the Wassermann test. 